\title{
Lead and Cadmium Level in Animal Organ Samples from Niger Delta, Nigeria
}

\author{
Okoye Esther, Orish Ebere Orisakweand, Nwaogazie Ifeanyi Lawrence
}

\begin{abstract}
Man questfor urbanization and industrialization has resulted to more pollutants introduced to the biosphere on a daily basis. Heavy metals are one form of pollutant that get into the biosphere and are transferred to humans through the intake of food contaminated with heavy metals, direct breathing of air contaminated with heavy metals and through skin contact which possess serious health concerns. The objective of this present study is to assess the heavy metals in animal organs in Niger Delta region of Nigeria. The metal concentration of lead $(\mathrm{Pb})$ and Cadmium $(\mathrm{Cd})$ were obtained in 84 meat and poultry samples using a Solar Thermo-Elemental Flame Absorption Spectrometer (S4 710). The result of the metal concentration showed that the liver of the animal organs tends to accumulates more heavy metals than any other animal organ parts. The highest mean metal concentration for lead $(9.56 \pm 3.95 \mathrm{ppm})$ was found in cow meat liverwhich was higher than the maximum limit of $0.5 \mathrm{ppm}$ for animal offal and $0.1 \mathrm{ppm}$ of animal meats. The highest mean concentration of cadmium was found in cow meat liver with a mean concentration of $0.02218 \pm 0.013 p p m$ while the lowest mean concentration of cadmium was found in broiler chicken muscle with a mean concentration of $0.00248 \pm 0.002 \mathrm{ppm}$. The result from the ANOVA showed that there was significant different in the mean metalconcentration for lead in the different animal organ but there was no significant different in the mean metal concentration for $\mathrm{Cd}$. The result of the study indicate that cow meat liver and muscles in the Niger Delta region in Nigeria are heavy polluted with heavy metal and should not be regularly consumed.
\end{abstract}

Index Terms - Animal organs, Heavy metals, Niger Delta Region.

\section{INTRODUCTION}

The anthropogenic activities of man has resulted to the constant pollution of the biosphere. Increase in industrialization and urbanization in developing countries has resulted to the release of environmental pollutants into the food chain resulting in elevatedlevel of heavy metal concentration in food consumed [1][2].The contamination of the biosphere with heavy metals are as a result of normal geological phenomena such as oreformation, leachingand weathering of rocks [3]. Other activities that also contribute to elevated concentration of heavy metal in the biosphere include burning of fossil fuels, smelting, discharge of industrial and domestic wastes, and the use of pesticide and

Esther Okoye, Occupational Health and Safetyin Africa Centre Of Excellence In Oil Field Chemicals Research, University of Port Harcourt, Rivers State Nigeria.

Orish Ebere, Occupational Health and Safetyin Africa Centre Of Excellence In Oil Field Chemicals Research, University of Port Harcourt, Rivers State Nigeria.

Nwaogazie Ifeanyi, Department of Civil and Environmental Engineering, University of Port Harcourt, Rivers State Nigeria. fungicide for agricultural activities. Oil exploration and oil spillage are also major sources of heavy metals release in the biosphere for countries that have oil fields [4]-[7]. Heavy metals in the biosphere are transferred through the food chain and are bio accumulated in animal organs (livers, muscles, bones etc) [8]. Animal organs are essential sources of protein to human and consumption of these organs possess serious health concerns if heavy metals are accumulated in them. Non-essential heavy metals like lead $\mathrm{Pb}$, mercury $\mathrm{Hg}$, Cadmium $\mathrm{Cd}$, and Arsenic As are very harmful when consumed irrespective of the level of concentration found in the animal organ, unlike essential heavy metals like Zinc Zn, Iron $\mathrm{Fe}$, Selenium $\mathrm{Se}$, and Copper $\mathrm{Cu}$ that becomes harmful when the maximum allowable limit is exceeded. Consumption of animal organs with high concentration of heavy metals lead to diseases such as cardiovascular, renal, nervous and skeletal diseases.

The Niger Delta is a region in Nigeria that predominately known for its oil exploration activities. Due to constant gas flaring and oil spillage various pollutants have been introduced to the region.Heavy metals and hydrocarbons contamination of the total environment (air, soil, water and biota) in the Nigeria's Niger Delta region has become a paramount interest and several studies have revealed levels and impacts considered toxic and dangerous [9]. This study aim at assessing the heavy metals in animal organ in the Niger Delta region.

\section{MATERIALS AND METHODS}

\section{A. Study Area}

The study areas used for this study were located in the Niger Delta region of Nigeria. The Niger Delta is the delta of the Niger River sitting directly on the Gulf of Guinea on the Atlantic Ocean. The Niger Delta region is located in the South-South geopolitical zone of Nigeria (See Fig. 1) that is made up of nine oil producing states namely Rivers, Delta, Edo, Ondo, Akwa Ibom, Abia, Imo, Ondo and Cross River. Animal organs samples were taken from three of the Niger Delta state namely Bayelsa, Akwa Ibom and Rivers states. The study area lies within the geographical coordinate of longitude $4^{\circ} 15^{\prime} \mathrm{N}-6^{\circ} 30^{\prime} \mathrm{N}$ and latitude $5^{\circ} 32^{\prime} \mathrm{E}-8^{\circ} 22^{\prime} \mathrm{E}$ of the lower Niger River in Nigeria. Fig. 1 shows location map of the study area. 


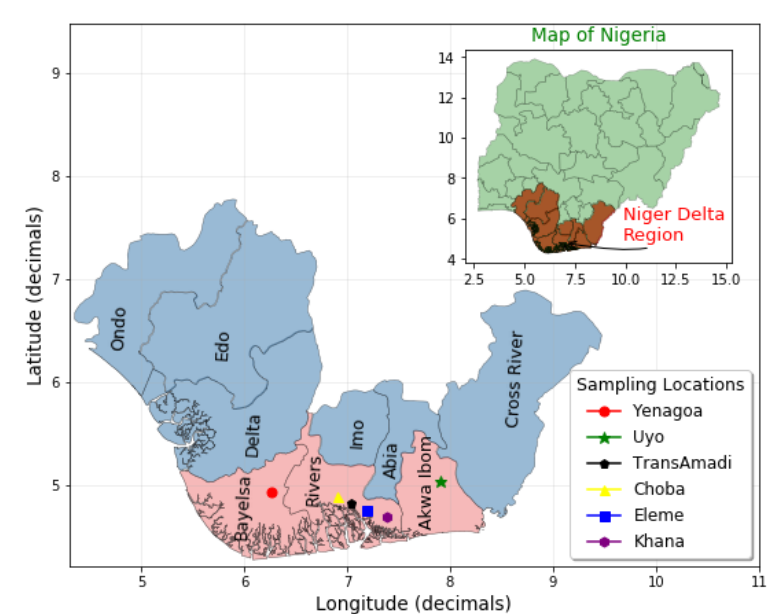

Fig 1: Map showing the sampling locations used for the study

B. Sample Collection and Preparation

Food samples namely cow meat liver and muscle, fresh fish samples, dried fish samples, native goat liver and muscle, goat meat from pepper soup, chicken suya, beef suya, fried meat, kilishi, native and broiler chicken muscle and gizzard were utilized in the present study. The cow and goat meat samples were collected directly from the Abattoirs, Two types of fresh fish samples (one from natural rivers and another from the pond) were also collected in the course of the study. Soil samples were collected with a metastenic stainless steel hand trowel. The hand trowel prior to collection was cleaned properly to prevent cross contamination. This was collected randomly at distance of $5 \mathrm{~m}$ alongside their corresponding soil samples. All samples were preserved at $-4^{0} \mathrm{c}$ in an ice pack and transported to the laboratory for analysis.

\section{Heavy Metal Determination}

Heavy metals $(\mathrm{Pb}$ and $\mathrm{Cd})$ in the samples were analyzed by a two-step process; dry-ashing and acid digestion. Fresh samples (meat and fish tissues) were oven-dried at $70^{\circ} \mathrm{C}$ for 24 hours while other samples were air dried for 24 hours. Dried samples weregrounded using a pestle and mortar and sieved through Muslin cloth. Five grams of each sample was digested in $9 \mathrm{~mL}$ of $65 \%$ concentrated HNO3 and $3 \mathrm{~mL}$ perchloric acid. The solution was transferred to a hot plate of $110^{\circ} \mathrm{C}$ for about 5 hours. Afterwards, the samples were introduced into an oven under a temperature that was gradually increased in $100^{\circ} \mathrm{C}$ every 60 minutes until the wished final temperature of $450^{\circ} \mathrm{C}$ was reached 18 hours later; white ashes were obtained. Following this, samples were left to cool. The white ashes were then dissolved with $1.5 \%$ HNO3 $(5 \mathrm{~mL})$ and a final volume of $25 \mathrm{~mL}$ was made by adding deionized water. The resulting solution was filtered using a Whatman filter paper (number 42) fitted into a Bucher funnel into a beaker before it was transferred into a tightly sealed plastic container. The presence of heavymetals $(\mathrm{Pb}, \mathrm{V}$, $\mathrm{Zn}, \mathrm{As}, \mathrm{Cu}, \mathrm{Hg}$ and $\mathrm{Cd}$ ) was determined using a Solar Thermo Elemental Flame Absorption Spectrometer (S4 710).

\section{Quality Control}

The instrument was recalibrated after every ten runs. The analytical procedure was checked using spike recovery method (SRM). A known standard of the metals was introduced into already analyzed samples and reanalyzed. The results of the recovery studies for $\mathrm{P} \mathrm{Cd}, \mathrm{Cr}, \mathrm{As}, \mathrm{Pb}, \mathrm{Ni}$, and $\mathrm{Sn}$, were more than $95 \%$. The relative standard deviation between replicate analyses was less than $4 \%$. The limit of detection (LOD) for lead and Cadmium was $0.001 \mathrm{ppm}$ with blank values reading as $0.00 \mathrm{ppm}$ for all the metals in deionized water with electrical conductivity value of lower than $5 \mu \mathrm{S} / \mathrm{cm}$. The limits of quantification LOQ for lead was 0.004 .

E. Data Analysis

Descriptive Statistic was carried out to determine the mean concentration and the standard deviation for level of concentration in the various animal organs. One-way analysis of variance (ANOVA) was used to determine whether the concentrations of the metals varied significantly, with values less than $0.05 \quad(\mathrm{p}<0.05)$ considered to be statistically significant. The statistical calculations were performed with XLSTAT software, 2016 version.

\section{RESULTS AND DISCUSSION}

A. Lead Concentration

The metal concentration of lead in the various animal organs in Niger Delta region in Nigeria as shown in Fig. 2 ranged from $1.684 \mathrm{ppm}$ to $14.728 \mathrm{ppm}$, with a mean metal concentration of $5.2656 \mathrm{ppm}$ and a standard deviation of $2.663 \mathrm{ppm}$. The mean metal concentration of lead in cow meat liver was $9.56 \pm 3.95 \mathrm{ppm}$, the mean metal concentration of lead in cow meat muscles was $7.76 \pm 3.74 \mathrm{ppm}$, the mean metal concentration of lead in fresh fish $A$ was $3.12 \pm 1.21 \mathrm{ppm}$ and the mean metal concentration of lead in fresh fish $\mathrm{B}$ was $4.14 \pm 3.17 \mathrm{ppm}$. The mean metal concentration of lead found in broiler chicken gizzard was higher than the mean metal concentration found in broiler chicken muscle which was reported by study done by [3]. The highest mean metal concentration was found in cow meat liver which was in agreement with most reports that lead is mostly accumulated in the liver than any other animal tissue [10]-[11] while the minimum mean metal concentration was observed in fresh fish A. Finding from this study showed that the mean concentration of lead in all the animal part used for this study were higher than the recommended limit set by the World Health Organisation (2011). According to WHO Standard, the recommended maximum limit of lead that can be in the meat of a cattle should be $0.1 \mathrm{mg} / \mathrm{kg}$ but from finding in our study the mean lead concentration in cow meat muscle, native goat muscle and Hausa goat muscle were 7.759, 4.883 and $5.550 \mathrm{mg} / \mathrm{kg}$ respectively. These results showed that the mean lead concentration in cattle and goat meat is way above the recommended limit. The maximum permissible limit for Cattle edible offal should be $0.5 \mathrm{mg} / \mathrm{kg}$, but result from our study showed that cow meat liver, native goat liver and Hausa goat liver had mean lead concentration of 9.555, 5.844 and $6.748 \mathrm{mg} / \mathrm{kg}$. The result showed that the mean metal concentration of lead in cattle edible offal was far above the recommended standard set by WHO. The maximum permissible limit for lead concentration in poultry meat should be $0.1 \mathrm{mg} / \mathrm{kg}$ but the mean concentration for the native chicken and broiler chicken muscle used for the study were 4.918 and $4.567 \mathrm{mg} / \mathrm{kg}$ respectively. The result showed that the mean concentration for poultry meat were far above the 
recommended limit. The maximum permissible limit for poultry edible offal should be $0.5 \mathrm{mg} / \mathrm{kg}$, but the mean concentration of native chicken and broiler chicken gizzard were 3.688 and $4.921 \mathrm{mg} / \mathrm{kg}$. The mean metal concentration were far above the recommended limit. The recommended limit of lead concentration in fish should be $0.3 \mathrm{mg} / \mathrm{kg}$ but result from our study showed that the mean concentration for various type of fished ranged from $3.116-4.161 \mathrm{mg} / \mathrm{kg}$.

The result from the study showed that lead concentration in animal protein in Niger Delta region of Nigeria is relatively very higher than recommended limit and can cause serious health effect on children that consume animal protein in the region. Some of the effect of lead on the human body are haematological effects, neurological and behavioural effects, renal effects, cardiovascular effects, and effects on the reproductive system [12].The effect of exposure to lead on human body is more severe in children and studies have shown that excessive lead in a child body can impair neurobehavioral functioning and impair neurobehavioral development in children which is a serious concern. Excessive lead in Adult can increase the systolic blood pressure of adults.

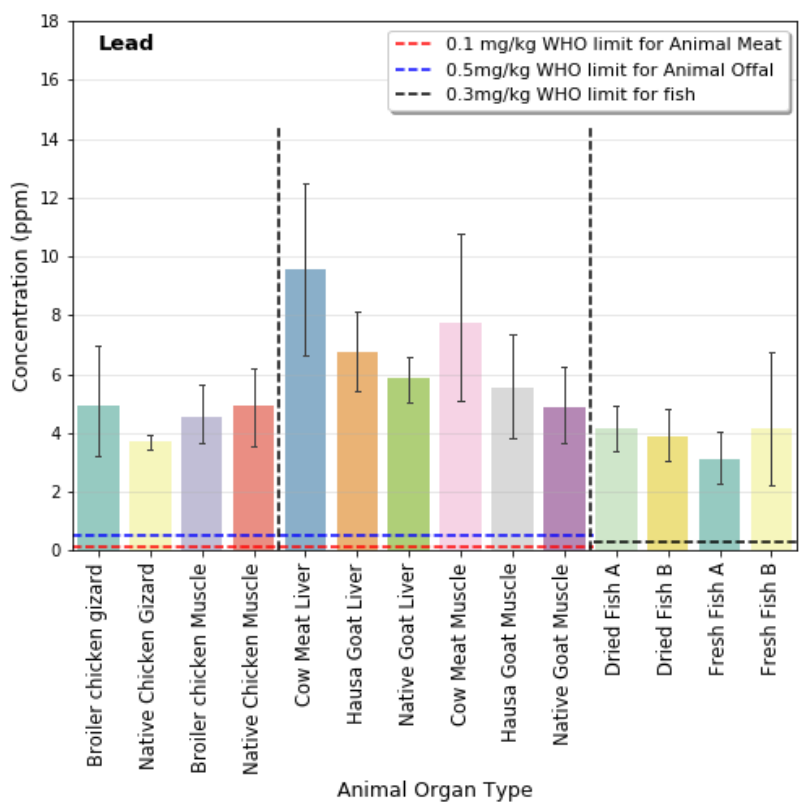

Fig 2: Barplot of heavy metal concentration of lead in animal organs in Niger Delta region of Nigeria

\section{B. Cadmium Concentration}

The metal concentration cadmium in the various animal organ used for the study ranged from 0.0772 to $0.0001 \mathrm{ppm}$, with a mean metal concentration of $0.01216 \mathrm{ppm}$ and a standard deviation of $0.0143 \mathrm{ppm}$. The mean metal concentration of cadmium in cow meat liver was $0.02218 \pm_{0.013 \mathrm{ppm}}$, the mean concentration of cadmium in cow meat muscle was $0.0216 \pm 0.011 \mathrm{ppm}$, the mean metal concentration of cadmium in native chicken gizzard was $0.00285 \pm 0.002 \mathrm{ppm}$ while the mean concentration of cadmium in broiler chicken muscle was $0.00248 \pm 0.002 \mathrm{ppm}$.

The highest mean concentration of cadmium was found in cow meat liver while the lowest mean concentration was found in broiler chicken muscle as shown in Fig. 3. From the study, it was observed that cadmium was predominately high in the muscles of animals organs while poultry meat had the lowest level of cadmium than other animal others. Cadmium are found more abundantly in organism that are natural accumulator of cadmium such as shellfish, crustacean and fungi than in cow or poultry meat. The recommended maximum intake limit of cadmium should be $0.5 \mathrm{mg} / \mathrm{kg}$ [12].

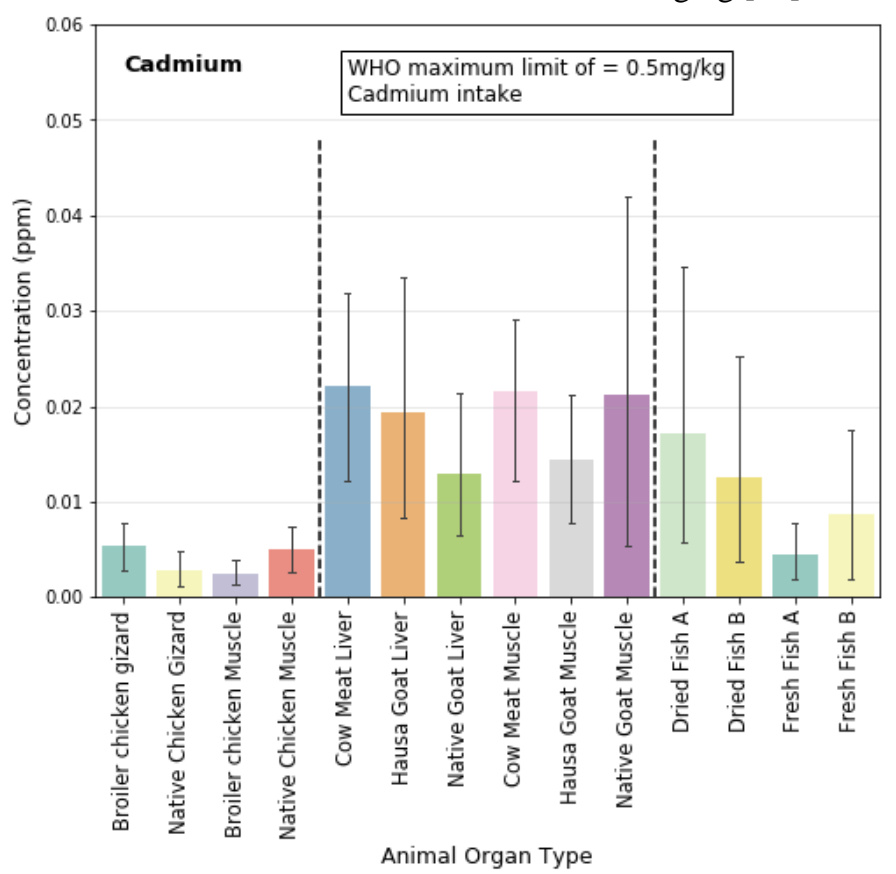

Fig 3: Barplot of heavy metal concentration of Cadmium in animal organs in Niger Delta region of Nigeria.

C. Analysis of Variance

A one way analysis of variance was perform to see if there is any significant difference between the concentration of heavy metals in the various animals organs. From Table 1, it was observed that there was significant difference at level of significant of 0.05 in the mean metal concentration of lead in the various animal organs. The mean concentration of lead in cow meat liver was significantly higher than the mean metal concentration of fresh fish $\mathrm{A}$, this indicate that the sources and the rate both animal accumulate lead were very much different. There was no significant different at level of significant of 0.05 in the mean metal concentration for Cadmium. The result for the one way ANOVA give one a better judgement that fresh fish A, native chicken gizzard and broiler chickengizzard are better sources of protein than cow meat liver and muscles because they significantly different and generally contain lower level of heavy metal accumulation in them. 
Table 1: Summary table for the mean, standard deviation and significant difference between the heavy meatal for different animal organ part for Niger Delta Nigeria

\begin{tabular}{|c|c|c|}
\hline Animal Organ Part & $\mathbf{P b}$ & Cd \\
\hline Cow meat liver & $9.555^{\mathrm{b} \pm} 3.953$ & $0.022^{\mathrm{a}} \pm 0.013$ \\
\hline Native goat liver & $5.844^{\mathrm{ab} \pm} 1.039$ & $0.013^{\mathrm{a}} \pm 0.010$ \\
\hline Hausa goat liver & $6.748^{\mathrm{ab} \pm 1.957}$ & $0.019^{\mathrm{a}} \pm 0.018$ \\
\hline Cow meat muscle & $7.759^{\mathrm{ab} \pm 3.736}$ & $0.022^{\mathrm{a}} \pm 0.011$ \\
\hline Native goat muscle & $4.883^{\mathrm{ab}} \pm 3.953$ & $0.021^{\mathrm{a} \pm 0.029}$ \\
\hline Hausa goat muscle & $5.550^{\mathrm{ab} \pm 2.383}$ & $0.014^{\mathrm{a}} \pm 0.009$ \\
\hline Native Chicken muscle & $4.918^{\mathrm{ab} \pm 1.803}$ & $0.005^{\mathrm{a}} \pm 0.003$ \\
\hline Broiler Chicken muscle & $4.567^{\mathrm{ab} \pm 1.374}$ & $0.003^{\mathrm{a}} \pm 0.002$ \\
\hline Fresh fish A & $3.116^{\mathrm{a} \pm} 1.210$ & $0.005^{\mathrm{a}} \pm 0.004$ \\
\hline Fresh fish B & $4.137^{\mathrm{ab} \pm 3.174}$ & $0.009^{\mathrm{a}} \pm 0.012$ \\
\hline Dried fish A & $4.161^{\mathrm{ab} \pm 1.038}$ & $0.017^{\mathrm{a} \pm 0.022}$ \\
\hline Dried fish B & $3.873^{\mathrm{ab} \pm 1.279}$ & $0.013^{\mathrm{a}} \pm 0.016$ \\
\hline Native Chicken Gizzard & $3.688^{\mathrm{ab} \pm 0.344}$ & $0.003^{\mathrm{a}} \pm 0.002$ \\
\hline Broiler Chicken Gizzard & $4.921^{\mathrm{ab} \pm 2.706}$ & $0.005^{\mathrm{a}} \pm 0.004$ \\
\hline
\end{tabular}

[8] Khalafalla, F. A., Ali, F. H., Schwagele, F. and Abd-El-Wahab, M. A, (2011):"Heavy metal residues in beef carcasses in Beni-Suef abattoir, Egypt," VeterinariaItaliana, 47 (3), 351-361.

\section{CONCLUSION}

The study showed that more heavy metals are accumulated in the liver of animal organs than any other part. Finding also revealed that cow meat liver and cow meat muscle are the two pollutant animal organs in the Nigeria Delta region and should not be consumed on a regular bases. Consumption of dried and fresh fishes as a source of protein is the best options for people who reside in the Niger Delta region of Nigeria as they don't contain high level of metal concentration. Poultry meat can also be consume as they don't contain heavy metal concentration as cow meat but elevated metal concentration of arsenic was found in poultry meat.

\section{DECLARATION OF INTEREST}

The authors report no conflicts of interest. The authors alone are responsible for the content and writing of this article.

\section{ACKNOWLEDGMENT}

The authors did not receive funding for the project from anybody.

\section{REFERENCES}

[1] Anyanwu, B. O., Ezejiofor, A. N., Igweze, Z. N and Orish, O.. (2018): Heavy Metal Mixture Exposure and Effects in Developing Nations: An Update. Toxic.Vol 6(4).

[2] Tchounwou, P. B., Yedjou, C. G., Patlolla, A. K., and Sutton, D. J. (2012). Heavy metal toxicity and the environment. Experientiasupplementum (2012), 101, 133-164. doi:10.1007/978-3-7643-8340-4_6.

[3] Uche, I.O, Oforka, N.C and Osuji, L.C (2012): Assessment of Heavy Metal Pollution in Muscles and Internal Organs of Chickens Raised in Rivers State, Nigeria. Journal of Emerging Trends in Engineering and Applied Sciences. Vol 3 (3) pp. 406-411

[4] Duffus, J.H (1980) Environmental Toxicology,Edward Arnold Publishers Limited, London. 21-103.

[5] Osibanjo, O and Jensen S (1961) Proceedings of the first national conference of water pollution and pesticide residues in food, University of Ibadan, Nigeria, 206-207.

[6] Hunt, J.M (1996): Petroleum geochemistry and geology; W.H Freeman and Company San Francisco. 231-238.

[7] Osuji, L.C (1998) Ph.D. Thesis, University of Ibadan, Nigeria.
[9] Ideriah T. J. K., David-Omiema S. , Ogbonna D. N. (2012) "Distribution of Heavy Metals in Water and Sediment along Abonnema Shoreline, Nigeria", Resources and Environment, Vol. 2 No. 1, pp. $33-40$

[10] Korenekova, B, Skalicka M, Nad P. (2002): Concentration of some heavy metals in cattle reared in the vicinity of a metallurgic industry. VeternarskiAshiv.72 (5): 259-267

[11] Miranda, M, Lopez-Alonso, M, Castillo C, HernadezJ, Benedito J.L (2005) Effect of Moderate pollution on toxic and trace metal levels in calves from apolluted area of Northern Spain. Environ Int. 31:543-548.

[12] World Health Organisation (WHO), Lead Environmental Health Criteria, Geneva: World Health Organization. Joint FAO/WHO Codex Committee on Contaminants in Foods, Food Standards Programme. The Hague: WHO/FAO. 2011. 